\title{
Creating an analysis model in order to identify solutions for sustainable development of ski areas in Romania
}

\author{
Mădălina Teodor, Robert Dobre, Laurențiu Ilie, Gabriel Stănoiu \\ Geomorphology - Pedology - Geomatics Department \\ Faculty of Geography, University of Bucharest \\ Bucharest, Romania
}

\begin{abstract}
The aim of this study is to analyze and assess the ski areas in Romania. To achieve this project were analyzed 92 resorts from Romanian. In this analysis were taken into account both geographical (position, accessibility, the ski slopes disposition in correlation with the slopes aspect, the slopes that influence the diversity of the ski areas, the ski areas visibility on the internet) and socio-economic factors (the services provided by the ski areas administrators, related tourism services, the state of the ski slopes, the types of the existing tourist facilities).
\end{abstract}

Keywords_-ski; develompent; suitable areas; efficienty

\section{INTRODUCTION}

For the study were made field analyze for all ski resort. Field analysis was combined with laboratory analysis by using GIS techniques. In order to identify the most complex ski areas in Romania were calculated several relevant indices. They were weighted and placed in a formula in order to achieve a ranking of functionality ski areas in Romania [1], [2].

\section{STUDY AREA}

The analysis was performed for all ski areas identified in Romanian Carpathians. We identified $256.6 \mathrm{~km}$ of ski slopes relate to the 266 ski slopes (111 easy slopes, 114 medium slopes, 40 difficult slopes). Cableway facility is composed by 5 lifts, 8 gondolas, 30 chair lifts, 140 ski lifts, 8 baby-ski and 5 conveyors.

The distribution ski areas map in the counties based on the number ski area, indicates the presence of 44 ski areas in Harghita county, 33 ski areas in Prahova County, 29 in Hunedoara county, 26 ski areas in the county of Maramures. Conversely, the fewest ski areas are recorded in Iasi, Bacau, Arges, Bacau, Gorj, Iaşi (1 ski area), Bihor and Bistrita Nasaud (by 3 ski areas), Neamt Mures (4 ski areas).

\section{Methodology}

In order to identify the most complex ski areas in Romania were calculated several relevant indices [2]. They were weighted and placed in a formula in order to achieve a ranking of functionality ski areas in Romania.

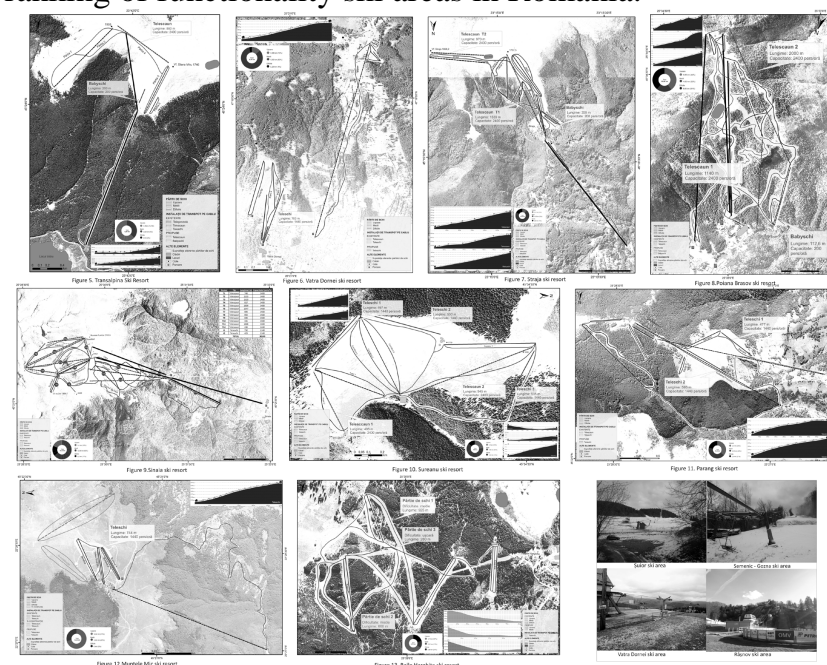

Fig. 1. Ski areas develpement proposed maps

Length index - is calculated by adding the lengths of all ski slopes in each area according to the formula: $\mathrm{Il}=$ Elp.

The rate of return is the ratio of the sum of all the slopes of a ski area and the amount of lift installations lengths. To calculate the rate of return was applied the formula (where $\mathrm{Rr}=$ return ski area, $\sum \mathrm{lp}=$ Sum of slopes lengths in the ski area, $\sum$ lp $=$ Sum of cable transport lengths area):

$$
R r=\frac{\sum l p}{\sum l t} \geq 1
$$

Transport index of ski areas indicates the maximum transport capacity of all lift facilities of a ski area. This index is calculated by summing the transport coefficients depending on the type of transport facilities in each ski area by applying the formula [2]: $\mathrm{Ct}=\sum \mathrm{It}$ where $\mathrm{Ct}=$ transport capacity and It = transport index.

The formula used to calculate the functionality of ski areas took into account three indicators (sum of lengths the ski slopes in every ski area with a share of $20 \%$, the 
rate of return was granted a share of $40 \%$ and the transport capacity using all facilities cableway of the resort - 40\%):

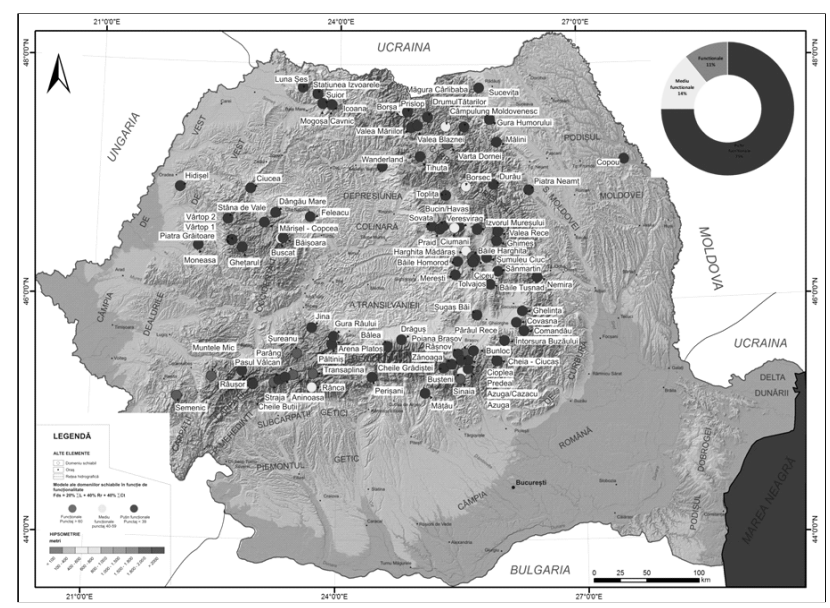

Fig. 2. Romanian ski areas location based on the functionality ski areas final score

TABLE II. SKI AREAS CLASSIFICATION DEPENDING ON FUNCTIONALITY

\begin{tabular}{|c|c|c|c|c|c|c|c|c|}
\hline Ski area & $\begin{array}{c}\text { Lengt } \\
\text { h } \\
(\mathrm{m}) \\
\end{array}$ & $\begin{array}{c}\text { Lengt } \\
\text { h } \\
\text { score }\end{array}$ & $\begin{array}{c}\text { Cable } \\
\text { way } \\
(\mathrm{m})\end{array}$ & $\begin{array}{c}\text { Rate } \\
\text { of } \\
\text { retur } \\
n\end{array}$ & $\begin{array}{c}\text { Rate } \\
\text { of } \\
\text { retur } \\
n \\
\text { score } \\
\end{array}$ & $\begin{array}{c}\text { Capa } \\
\text { city } \\
\text { factor } \\
\text { (pers/ } / \\
\text { h) }\end{array}$ & $\begin{array}{c}\text { Capa } \\
\text { city } \\
\text { factor } \\
\text { score }\end{array}$ & $\begin{array}{c}\text { Fi } \\
\text { nal } \\
\text { sco } \\
\text { re } \\
\end{array}$ \\
\hline Semenic & 10415 & 20 & 2950 & 3,53 & 40 & 36 & 40 & $\begin{array}{c}10 \\
0 \\
\end{array}$ \\
\hline Sinaia & 19878 & 20 & 9895 & 2,01 & 20 & 100 & 40 & 80 \\
\hline Straja & 20014 & 20 & 7651 & 2,62 & 20 & 80 & 40 & 80 \\
\hline Șureanu & 9410 & 20 & 1830 & 5,14 & 40 & 24 & 20 & 80 \\
\hline $\begin{array}{l}\text { Poiana } \\
\text { Brașov } \\
\end{array}$ & 22060 & 20 & 11412 & 1,93 & 10 & 98 & 40 & 70 \\
\hline Parâng & 9420 & 20 & 7170 & 1,31 & 10 & 54 & 40 & 70 \\
\hline $\begin{array}{c}\text { Băile } \\
\text { Harghita }\end{array}$ & 4759 & 10 & 1920 & 2,48 & 20 & 30 & 40 & 70 \\
\hline $\begin{array}{c}\text { Transalp } \\
\text { ina Ski } \\
\text { Resort }\end{array}$ & 6092 & 10 & 5346 & 1,14 & 10 & 72 & 40 & 60 \\
\hline $\begin{array}{l}\text { Vatra } \\
\text { Dornei }\end{array}$ & 6799 & 10 & 5756 & 1,18 & 10 & 38 & 40 & 60 \\
\hline $\begin{array}{c}\text { Muntele } \\
\text { Mic }\end{array}$ & 4652 & 10 & 3130 & 1,49 & 10 & 30 & 40 & 60 \\
\hline
\end{tabular}

For calculating the employment rate to establish a model of sustainable development it is necessary to calculate the optimum number of skiers on a ski slope. To determine the optimum number of skiers who may find themselves simultaneously on a ski slope was considered a square of $12 \mathrm{~m}$. The area ski areas were divided by the area of a square (144 square kilometres) to obtain the number of squares covering ski area.

We applied the next formula in order to determine the optimum number of skiers who can be simultaneously on the slope, knowing the number of squares covering the surface of the ski area:

$$
\mathbf{O}=2 \mathbf{P}+2
$$

Where: $\mathrm{O}=$ the optimum number of skiers at a time on the slope, $\mathrm{P}=$ the number of squares covering the surface of the ski area.
The optimal rate of occupancy of a ski slope indicates that is the ratio between the optimum number of skiers that ski simultaneously on a ski slope without bothering each other and the maximum number of skiers on the facility cableway may transport. To determine the optimal rate of occupancy the next formula was applied:

$$
R o=\frac{2 P+2}{\sum I t * 100}=\frac{2 P+2}{C t * 100}=\frac{o}{C c}
$$

Comfort factor (CcF) was calculated by applying the formula:

$$
\mathrm{Ccf}=\sum \mathrm{It} * 100-(2 \mathrm{P}+2)=\mathrm{Ct} * 100-(2 \mathrm{P}+2)=\mathrm{Cc}-\mathrm{O} \text { (4). }
$$

\section{RESULTS AND CONCLUSIONS}

To optimize the functionality of ski areas were identified some solutions to increase profit ski areas. It is noted that most major ski areas in the country have a low capacity cable transport facilities. This is transposed in the comfort of skiers who often queue to be able to reach the top of the ski slopes while round skiing surface is utilized to the maximum.

Depending on the occupancy rate (Ro) and the comfort factor (CCF) calculated for the ten ski areas were proposed following development maps:

The advantages of this analysis are numerous. It is noticed: the incretion of the resort visibility in the country, increasing the attractiveness and the competitiveness of the ski areas. Also, it is noticed the need to satisfy the requirements of a wider range of skiers, practicing smart tourism, attracting tourists from further afield, foreign tourists or the possibility of using the new infrastructure for practicing various mountain activities (mountain biking, hiking, recreation) for at the resorts situated at the end of the ranking [4].

From the analysis achieved in the field, we observed that the improvement of the provided services and the proper management of the ski area determines tourist's loyalty and thus increase their number.

Looking at the major European mountain resorts there is a better use of the ski area, sound management and integrated management of tourist facilities and infrastructure used by skiers. It wants to implement a comparable system in the Romanian Carpathian area.

In conclusion, by calculating all these indices for the ski areas (index transmission rate of return, occupancy, rate of transport), there was a need to develop cableway facilities in $90 \%$ of case studies analysed (Semenic, Sinaia, Straja, Șureanu, Poiana Brașov, Parâng, Transalpina Ski Resort, Vatra Dornei, Muntele Mic). Thus, using analysis (done on the field and working with GIS techniques) was observed the cableway inefficiency (identification of overcrowding at the starting stations starting stations and low density of skiers on the ski slopes), which have a capacity maximum carrying less than the number of skiers, especially on weekends or during holidays.

\section{REFERENCES}

[1] M. Teodor and R. Dobre, "Relief suitability for developing a macro ski area between Predeal and Azuga Resorts", Revista de Geomorfologie, vol. 17, pp. 95-106, 2015. 
[2] M. Teodor, "Proiectarea, dezvoltarea și managementul domeniilor schiabile din România”, teză de doctorat, 2016. (in Romanian)

[3] M. Teodor, I. Laurențiu, and R. Dobre, "Using GIS techniques to create the catalog of Romanian ski resorts", Analele Universități din București, seria Geografie, Nr. LXV, pp. 81-92, 2016.
[4] M. Voiculescu, F. Popescu, T. M. Oance, M. Olaru, and A. Onaca, "Features of ski area from the Romanian Banat", Forum geografic. Studii și cercetări de geografie și protecția mediului, vol. 10, no. 1, pp. 58-69. doi: 10.5775/fg.2067-4635.2011.019.i 